\title{
Studi Eksperimental Laju Keausan Material Gigi Tiruan dari Resin Akrilik Berpenguat Fiberglass dengan Variasi Susunan Serat Penguat
}

\author{
Prastika Kristasari dan Yusuf Kaelani \\ Jurusan Teknik Mesin, Fakultas Teknologi Industri, Institut Teknologi Sepuluh Nopember (ITS) \\ Jl. Arief Rahman Hakim, Surabaya 60111 Indonesia \\ e-mail:y_kaelani@me.its.ac.id
}

\begin{abstract}
Abstrak- Resin akrilik adalah salah satu material yang mulai banyak digunakan sebagai salah satu material untuk pembuatan gigi tiruan. Penelitian sebelumnya tentang analisis pengujian laju keausan resin akrilik berpenguat serat pada dental prosthesis pada kondisi dry sliding menunjukkan hasil nilai laju keausan berkurang dengan adanya penambahan serat[1]. Saat ini belum ada kajian mengenai laju keausan resin akrilik berpenguat serat pada kondisi wet sliding dengan variasi pola susunan serat yang berbeda dengan kondisi terendam cairan saliva buatan. Metode pengujian ekperimental ini menggunakan alat uji keausan tribometer tipe pin on disk. Material untuk pin dan disk menggunakan material dari resin akrilik berpenguat serat. Disk diputar dan bergesekan dengan pin. Variabel tetap pengujian ini yaitu panjang lintasan sejauh $505,92 \mathrm{~m}$, beban sebesar $2 \mathrm{~kg}$, dan sliding speed sebesar $0,07 \mathrm{~m} / \mathrm{s}$. Perlakuan gesekan dilakukan pada resin akrilik berpenguat serat dengan variasi susunan serat $0 \%, 7 \%$ berpola $6 \mathrm{~mm}$ serat acak, dan $7 \%$ berpola $6 \mathrm{~mm}$ serat teratur. Spesimen direndam dahulu dan saat pengujian keausan dikondisikan terendam dalam cairan saliva buatan. Kemudian, spesimen tersebut dianalisis laju keausannya dan diamati gambar mikro dari permukaan spesimen. Hasil dari penelitian adalah data pengujian berupa nilai laju keausan spesifik terbesar sebesar $0.0126 \mathrm{~mm}^{3} / \mathrm{Nm}$ yang terdapat pada material resin akrilik tanpa penguat serat dan nilai laju keausan yang terkecil yaitu pada material resin akrilik berpenguat $7 \%$ serat berpola teratur sebesar $0.0006 \mathrm{~mm}^{3} / \mathrm{Nm}$. Hasil foto mikro menunjukkan bahwa mekanisme keausan yang paling dominan terjadi adalah keausan abrasif dan keausan fatigue.
\end{abstract}

Kata Kunci-fiberglass, wear rate, resin akrilik, gigi tiruan.

\section{PENDAHULUAN}

$\mathbf{P}$ ERKEMBANGAN ilmu-ilmu baru dan perpaduan ilmu pengetahuan menimbulkan perpaduan antara ilmu teknik, biologi, dan kedokteran yang disebut biomedical engineering. Material yang digunakan sebagai material biomedical disebut biomaterial. Biomaterial harus memiliki sifat fisik dan mekanik yang memadai untuk berfungsi sebagai pengganti jaringan tubuh. Material resin akrilik ini sebagai salah satu material yang saat ini mulai dikembangkan sebagai bahan pembuatan gigi tiruan[1].

Dalam penggunaan sehari-hari, bahan restorasi gigi tiruan ini diharapkan dapat bertahan dengan baik di dalam mulut. Proses pengunyahan makanan menyebakan material tersebut akan saling mengalami kontak sehingga terjadi gesekan satu sama lain yang dikenal dengan keausan (wear). Material yang digunakan sebagai bahan restorasi gigi tiruan ini haruslah memiliki ketahanan aus (wear resistant) yang baik. Keausan merupakan hilangnya materi dari permukaan benda padat sebagai akibat dari gerakan mekanik. Keausan umumnya timbul sebagai akibat interaksi mekanik antara dua permukaan yang bergerak sliding dan diberikan beban tertentu. Faktor yang mempengaruhi keausan antara lain kecepatan gerak, tekanan, besarnya pembebanan, kekasaran permukaan, kekerasan bahan, dan kekuatan bahan. Apabila keausan ini terus terjadi akan menyebabkan kerusakan material.

Material resin akrilik sampai saat ini masih merupakan pilihan untuk pembuatan gigi tiruan karena tidak mengandung bahan berbahaya, memiliki tingkat warna yang dapat disesuaikan dengan warna gigi asli, harganya relatif murah, mudah direparasi, proses pembuatannya mudah, dan dapat dibuat dengan peralatan sederhana. Penelitian ini menganalisis dan mengkaji kembali laju keausan material gigi tiruan dari resin akrilik berpenguat $7 \%$ fiberglass dengan variasi susunan serat penguat yang berpola $6 \mathrm{~mm}$ serat teratur, $6 \mathrm{~mm}$ serat acak, dan resin akrilik berpenguat 0\% fiberglass sebagai spesimen kontrol. Dari hasil penelitian didapatkan hasil berupa perbandingan laju keausan material dan mekanisme keausan yang dominan terjadi.

\section{METODE PENELITIAN}

\section{A. Variabel dan Input Pengujian}

Pada penelitian ini, dilakukan studi eksperimental dimana menggunakan variabel-variabel uji, yaitu sebagai berikut:

1) Spesimen pin yang digunakan dalam studi eksperimental ini yaitu:

a) 3 Pin $\mathrm{A}$ berbahan resin akrilik berpenguat $0 \%$ fiberglass

b) 3 Pin $\mathrm{B}$ berbahan resin akrilik berpenguat $7 \%$ fiberglass dengan susunan serat penguat yang berpola $6 \mathrm{~mm}$ serat teratur

c) 3 Pin $\mathrm{C}$ berbahan resin akrilik berpenguat $7 \%$ fiberglass dengan susunan serat penguat yang berpola $6 \mathrm{~mm}$ serat acak 
2) Spesimen pin direndam dalam cairan saliva buatan selama 10 jam dan terendam saliva buatan saat dilakukan uji keausan selama 136 menit.

3) Spesimen disk dari material resin akrilik berpenguat $7 \%$ fiberglass berpola acak.

Pada penelitian penelitian ini menggunakan input-input pengujian, yaitu sebagai berikut:

1) Beban yang digunakan adalah sebesar $2 \mathrm{~kg}$.

2) Nilai sliding speed yang digunakan untuk pengujian ini yaitu sebesar $0.07 \mathrm{~m} / \mathrm{s}$.

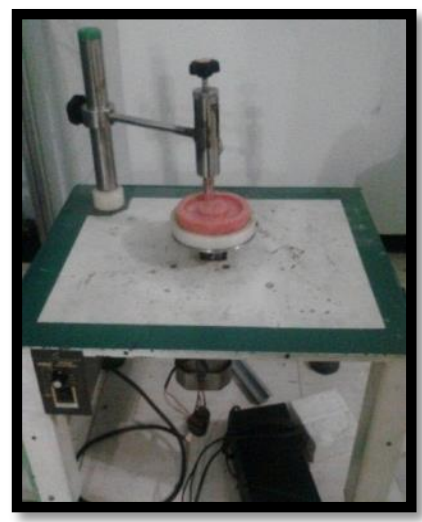

Gambar 1. Pengujian keausan dengan tribometer tipe pin on disk

\section{B. Massa dan Densitas Komposit}

Berikut ini adalah jumlah komposisi serat yang ditambahkan pada material uji pin, yaitu:

1) Spesimen pin dengan komposisi $100 \%$ resin, $0 \%$ serat

$$
\begin{aligned}
& >m_{\text {resin }}=V_{\text {resin }} \times \rho_{\text {resin }} \\
& \text { > } m_{\text {resin }}=1,767 \mathrm{~cm}^{3} \times 1,19 \frac{\mathrm{gr}}{\mathrm{cm}^{3}} \\
& \text { > } m_{\text {resin }}=2,1 \mathrm{gram}
\end{aligned}
$$

2) Spesimen pin dengan komposisi $93 \%$ resin, $7 \%$ serat

$$
\begin{aligned}
& >\quad m_{\text {serat }}=\frac{7}{100} \times V_{\text {resin }} \times \rho_{\text {serat }} \\
& >\quad m_{\text {serat }}=\frac{7}{100} \times 1,767 \mathrm{~cm}^{3} \times 2,54 \frac{\mathrm{gr}}{\mathrm{cm}^{3}} \\
& >\quad m_{\text {serat }}=0,31 \mathrm{gram}
\end{aligned}
$$

Berikut ini merupakan perhitungan densitas komposit pada spesimen uji dengan variasi susunan serat, yaitu:

$$
\begin{aligned}
& >\quad m_{c}=m_{\text {serat }}+m_{\text {resin }} \\
& >\quad\left(\rho_{c} \times V_{c}\right)=\left(\rho_{\text {serat }} \times V_{\text {serat }}\right)+\left(\rho_{\text {resin }} \times V_{\text {resin }}\right)
\end{aligned}
$$

Tabel 1.

Data densitas spesimen uji

\begin{tabular}{clllll}
\hline \hline $\begin{array}{l}\text { Pola } \\
\text { Pin }\end{array}$ & $\begin{array}{l}\text { Nama } \\
\text { Pin }\end{array}$ & $\begin{array}{l}\text { Massa } \\
\text { Serat } \\
(\mathrm{gram})\end{array}$ & $\begin{array}{l}\text { Massa } \\
\text { Jenis } \\
\text { Serat } \\
\left(\mathrm{gr} / \mathrm{cm}^{3}\right)\end{array}$ & $\begin{array}{l}\text { Massa } \\
\text { Jenis } \\
\text { Resin } \\
\left(\mathrm{gr} / \mathrm{cm}^{3}\right)\end{array}$ & $\begin{array}{l}\text { Massa } \\
\text { Jenis } \\
\text { Komposit } \\
\left(\mathrm{gr} / \mathrm{cm}^{3}\right)\end{array}$ \\
\hline 0\% & A1 & 0 & 2,54 & 1,19 & 1,19 \\
Serat & A2 & 0 & 2,54 & 1,19 & 1,19 \\
& A3 & 0 & 2,54 & 1,19 & 1,19 \\
$7 \%$ & B1 & 0,31 & 2,54 & 1,19 & 1,28 \\
Teratur & B2 & 0,31 & 2,54 & 1,19 & 1,28 \\
& B3 & 0,31 & 2,54 & 1,19 & 1,28 \\
$7 \%$ & C1 & 0,31 & 2,54 & 1,19 & 1,28 \\
Acak & C2 & 0,31 & 2,54 & 1,19 & 1,28 \\
& C3 & 0,31 & 2,54 & 1,19 & 1,28 \\
\hline \hline
\end{tabular}

\section{Langkah Kerja Penelitian}

Penelitian ini dilakukan melalui beberapa langkah kerja studi ekperimental yaitu:

1) Melakukan studi pustaka sebagai dasar melakukan penelitian penelitian ini.

2) Pengukuran massa awal spesimen pin $\mathrm{A}$, B, dan $\mathrm{C}$ dilakukan dengan menggunakan timbangan digital.
3) Penentuan jarak radius spesimen antara pin dengan disk sebesar 0,04 meter.

4) Mempersiapkan alat uji tribometer pin on disk dan melakukan kalibrasi alat uji untuk speed control, variable load, dan pengaturan semua komponen dari tribometer.

5) Memberikan input pembebanan $2 \mathrm{~kg}$ dan speed control pada level 20 yang setara dengan kecepatan sebesar $0,07 \mathrm{~m} / \mathrm{s}$

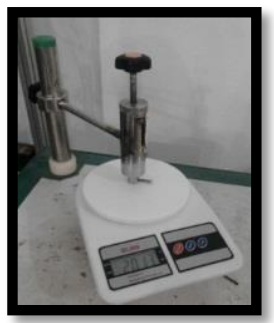

Gambar 2. Kalibrasi massa

Putaran diukur dengan menggunakan alat tachometer dan didapatkan rpm dari speed control pada level 20 yaitu sebesar 14,8 rpm.

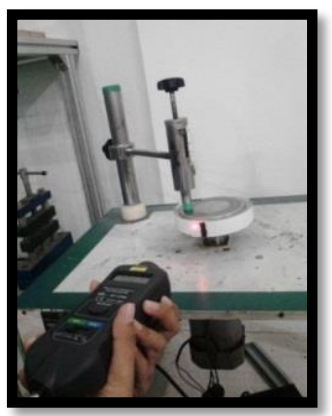

Gambar 3. Kalibrasi kecepatan putaran

6) Melakukan perendaman pada masing-masing spesimen pin $\mathrm{A}, \mathrm{B}$, dan $\mathrm{C}$ di dalam cairan saliva buatan selama 10 jam.

7) Menimbang kembali massa masing-masing spesimen pin $\mathrm{A}, \mathrm{B}$, dan $\mathrm{C}$ yang telah selesai direndam dengan menggunakan timbangan digital.

8) Selama pengujian keausan, panjang wear track dibuat konstan sepanjang 505,92 meter dengan waktu pengujian selama 136 menit.

9) Melakukan pengujian keausan yaitu spesimen uji pin $\mathrm{A}, \mathrm{B}$, dan $\mathrm{C}$ yang dikondisikan terlubrikasi saliva buatan saat bergesekan dengan disk.

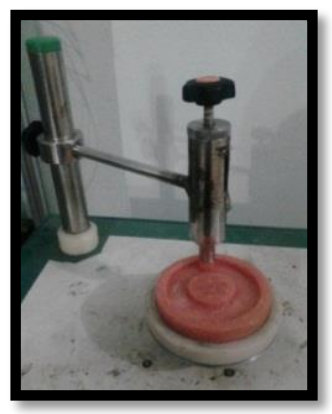

Gambar 5. Pin spesimen yang digesek saat pengujian

10) Menimbang massa akhir untuk setiap spesimen A, B, dan $\mathrm{C}$.

11) Melakukan pengambilan foto mikro permukaan dari material spesimen uji pin $\mathrm{A}, \mathrm{B}$, dan $\mathrm{C}$ yang telah diuji 
di Laboratorium Metalurgi Teknik Mesin ITS untuk mengetahui mekanisme laju keausan.

12) Mengolah data hasil pengujian, menganalisis grafik, serta menganalisis mekanisme laju keausan (wear rate) dari hasil pengujian struktur permukaan

\section{Rancangan Penelitian}

Perubahan massa pin $(\Delta \mathrm{m})$ merupakan nilai selisih dari massa pin setelah dilakukan perendaman dan massa akhir setelah dilakukan pengujian. Adanya selisih massa ini menunjukkan terjadinya keausan pada material yang ditandai dengan berkurangnya nilai massa. Adapun nilai $\Delta \mathrm{V}$ ini dapat dihitung dengan menggunakan rumus yaitu sebagai berikut ini:

$$
\Delta V=\frac{\Delta m}{\rho}
$$

Keterangan:

$\Delta \mathrm{m}=$ perubahan massa pin atau volume keausan $($ gram $)$

$\rho \quad=$ massa jenis material komposit $\left(\mathrm{gram} / \mathrm{cm}^{3}\right)$

$\Delta \mathrm{V}=$ perubahan volume pin $\left(\mathrm{cm}^{3}\right)$

Kemudian, laju keausan material (K') dapat dihitung dengan menggunakan rumus:

$$
K^{\prime}=\frac{\Delta V}{F \cdot L}
$$

Keterangan:

$$
\begin{aligned}
& \mathrm{K}^{\prime}=\text { nilai laju keausan spesifik }\left(\mathrm{mm}^{3} / \mathrm{Nm}\right) \\
& \Delta \mathrm{V}=\text { perubahan volume pin }\left(\mathrm{cm}^{3}\right) \\
& \mathrm{F} \quad=\text { beban normal }(\mathrm{N}) \\
& \mathrm{L} \quad=\text { panjang wear track }(\mathrm{m})
\end{aligned}
$$

\section{ANALISIS PENELITIAN}

\section{A. Karakteristik Fiber Reinforced Composite (FRC)}

Fiber reinforced composite mulai banyak digunakan pada bidang industri dan aplikasi aerospace karena ringan, kuat dan tidak mudah terbakar. Sedangkan di dunia kedokteran gigi, material fiber reinforced composite ini sudah mulai dikembangkan penggunaannya sebagai material gigi tiruan. Material ini menjadi pertimbangan karena sifat mekaniknya yang bagus, memiliki estetika yang bagus dan kemampuan yang bagus dalam berikatan dengan material resin komposit pada kedokteran gigi[6]. Ketahanan dari material fiber reinforced composit ini berhubungan dengan properties dari masing-masing fiber dan resin, impregnasi fiber dengan resin, adhesi serat dengan resin, volume fiber pada matrik resin, orientasi dari fiber dan letak fiber pada prosthesis.

Penelitian yang dilakukan oleh David J. Callaghan, Ashkan Vaziri, dan Hamid Nayeb-Hashemi (2006), yang berjudul Effect of fiber volume fraction and length on the wear characteristics of glass fiber-reinforced dental composite, dimana menggunakan material dental resin dengan penambahan glass fiber. Spesimen diuji dengan menggunakan pin on disk. Normal load yang diaplikasikan bervariasi antara $4.45-22.24 \mathrm{~N}$, dimana pemberian beban ini disesuaikan pada kondisi mastikasi (pengunyahan). Dari hasil penelitian ini dapat disimpulkan bahwa spesimen $2 \%$ dan 7,6\% FRC memiliki wear volume yang paling besar. Untuk pengaruh dari lebar serat, spesimen dengan panjang serat $3 \mathrm{~mm}$ memiliki wear rate yang lebih rendah bila dibandingkan dengan spesimen dengan panjang serat 1.5 $\mathrm{mm}[2]$.

Gaya oklusi (gaya vertical) selama gigi mengunyah dan menelan dengan berbagai jenis makanan adalah sekitar 70 N. Dalam persamaan tekanan, $\mathrm{P}=\mathrm{F} / \mathrm{A}$, dimana gaya berbanding lurus dengan luasan permukaan. Pada gigi molar memiliki luasan oklusal dan ligament periodonsium yang paling besar yaitu $451 \mathrm{~mm}^{2}$, sehingga tekanan yang diterima gigi sekitar $0.15 \mathrm{~N} / \mathrm{mm}^{2}$. Pada spesifikasi tribometer dan spesimen, yang digunakan pada penelitian ini, tekanan yang dihasilkan dengan pembebanan $2 \mathrm{~kg}$ dan luas permukaan dari spesimen adalah $176 \mathrm{~mm}^{2}$ adalah sebesar $0.11 \mathrm{~N} / \mathrm{mm}^{2}$.

Pada penelitian yang dilakukan oleh Zuriah Sitorus dan Eddy Dahar (2012), yang berjudul "Perbaikan Sifat Fisis dan Mekanis Resin Akrilik Polimerisasi Panas dengan Penambahan Serat Kaca", melakukan analisis terhadap RAPP (Resin Akrilik Polimerisasi Panas) untuk membandingkan sifat fisis dan mekanik RAPP yang ditambah serat kaca dengan RAPP tanpa penambahan serat kaca. Serat kaca yang digunakan adalah produk Taiwan Glass berukuran 4mm, $6 \mathrm{~mm}$, dan $8 \mathrm{~mm}$ sebanyak $1 \%$ dari total volume RAPP. Dari hasil pengujian tersebut, dieperoleh hasil bahwa RAPP dengan penambahan serat 6 mm merupakan RAPP yang menghasilkan peningkatan kualitas fisis dan mekanis yang optimum[3].

\section{B. Gerakan Gigi saat Pengunyahan}

Mengunyah atau mastikasi adalah proses penghancuran makanan secara mekanik yang terjadi di dalam rongga mulut dan melibatkan organ-organ di dalam rongga mulut seperti, gigi-geligi, rahang, lidah, palatum, dan otot-otot pengunyahan. Penghancuran makanan yang dihasilkan karena adanya kekuatan saat mengunyah. Besarnya kekuatan mengunyah dapat digolongkan atas empat kelompok yaitu : low (besar kekuatan $<59$ pon), medium low (besar kekuatan 59- 100 pon), medium high (besar kekuatan 101-144 pon), dan high (besar kekuatan > 144 pon) [4].

Shear strength merupakan ketahanan suatu material terhadap gesekan yang terjadi dimana gaya gesek ini dihasilkan dari gesekan dua permukaan yang paralel dengan arah yang berlawanan satu dengan lainnya. Gaya gesek biasanya timbul pada saat mastikasi terutama saat menggerus makanan. Pada saat proses pengunyahan berlangsung maka akan terjadi tiga gaya sekaligus yaitu gaya kompresi yang paling banyak berperan, gaya tarik, serta gaya gesek. Gaya gesek ini timbul akibat adanya gesekan antara makanan dengan gigi pada saat pengunyahan[4].

Dalam gerakan ini, gigi mengalami gesekan antar permukaan gigi. Gerakan gesekan antar gigi ini termasuk salah satu gerak gaya gesek statis. Gaya gesekan statis cenderung mempertahankan keadaan diam benda. Hal ini sesuai dengan kondisi rahang gigi manusia yang diam.

$$
\text { Gaya pengunyahan vertikal }
$$

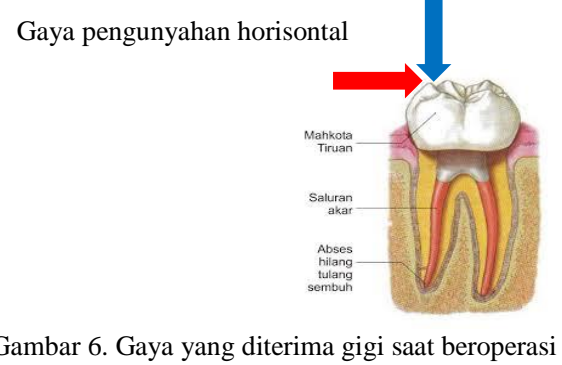

Gambar 6. Gaya yang diterima gigi saat beroperasi 


\begin{tabular}{clllll}
\multicolumn{7}{c}{} & &
\end{tabular}

Gambar 7. Skema gerakan gigi (a) sebelum pengunyahan, dan (b) setelah pengunyahan[5]

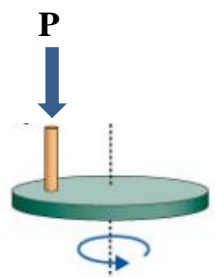

Gambar 8. Skema gaya gesek pada alat uji

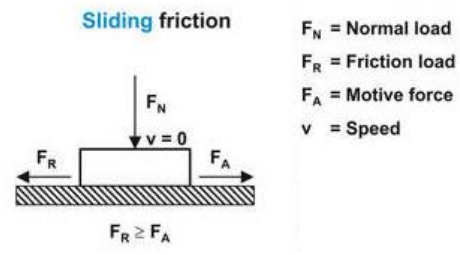

Gambar 9. Skema sliding contact[6]

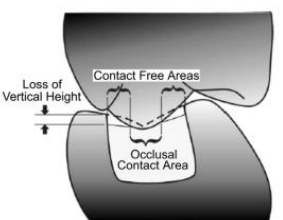

Gambar 10. Area gigi yang mengalami sliding contact

Berikut ini adalah secara rinci parameter-parameter pada saat pengunyahan oleh gigi manusia, yaitu:

Tabel 2.

Interoral Chewing Parameters[5]

\begin{tabular}{llllll}
\hline \multicolumn{7}{c}{ Interoral Chewing Parameters $[5]$} & \\
Chewing load $(\mathrm{N})$ & $\begin{array}{l}\text { Chewing } \\
\text { frequency }(\mathrm{Hz})\end{array}$ & $\begin{array}{l}\text { Sliding speed } \\
(\mathrm{mm} / \mathrm{s})\end{array}$ & $\begin{array}{l}\text { Sliding } \\
\text { distances }(\mathrm{mm})\end{array}$ & \begin{tabular}{l} 
Duration $(\mathrm{s})$ \\
\cline { 5 - 7 } Total
\end{tabular} & Occlusion \\
\hline $2-150$, Max 450 & $1-2$ & $0.25-0.50$ & $0.9-1.2$ & 0.70 & 0.10 \\
\hline
\end{tabular}

Source: From Lewis and Dwyer-Joyce [26], Sajewicz and Kulesza [27], and Rees and Jagger [35]

\section{Pengujian Keausan}

Pada pengujian keausan menunjukkan data nilai massa sesudah pengujian lebih kecil daripada sebelum pengujian yaitu nilai massa setelah direndam karena terdapat massa yang hilang akibat terkikis saat pengujian keausan. Spesimen yang telah direndam menunjukkan data nilai massa setelah direndam lebih besar daripada data nilai massa sebelum direndam karena resin akrilik memiliki sifat menyerap air. Bahan resin akrilik mempunyai sifat yaitu menyerap air secara perlahan-lahan dalam jangka waktu tertentu[6]. Berikut ini disajikan tabel hasil pengujian laju keausan resin akrilik berpenguat serat.
Tabel 3.

Hasil pengujian

\begin{tabular}{lllll}
\hline \hline Pola Pin & $\begin{array}{l}\text { Nama } \\
\text { Pin }\end{array}$ & $\begin{array}{l}\text { Sebelum } \\
\text { Direndam } \\
\text { (gram) }\end{array}$ & $\begin{array}{l}\text { Sesudah } \\
\text { Direndam } \\
\text { (gram) }\end{array}$ & $\begin{array}{l}\text { Sesudah } \\
\text { Diuji } \\
\text { (gram) }\end{array}$ \\
\hline 0\% Serat & A1 & 3,0556 & 3,155 & 3,077 \\
& A2 & 3,1653 & 3,2514 & 3,1391 \\
$7 \%$ Teratur & A3 & 2,9086 & 3,0067 & 2,858 \\
& B1 & 3,2496 & 3,2509 & 3,2436 \\
& B2 & 3,1803 & 3,1846 & 3,1731 \\
$7 \%$ Acak & B3 & 3,3225 & 3,3489 & 3,3207 \\
& C1 & 3,0485 & 3,0697 & 3,0121 \\
& C2 & 3,0514 & 3,1064 & 3,0483 \\
& C3 & 3,4092 & 3,4566 & 3,3965 \\
\hline \hline
\end{tabular}

\section{Analisa Laju Keausan Spesimen Uji}

Pada pengujian keausan yang telah dilakukan didapatkan bahwa nilai specific wear rate ditunjukkan pada tabel berikut ini:

Tabel 4.

Nilai specifik wear rate spesimen

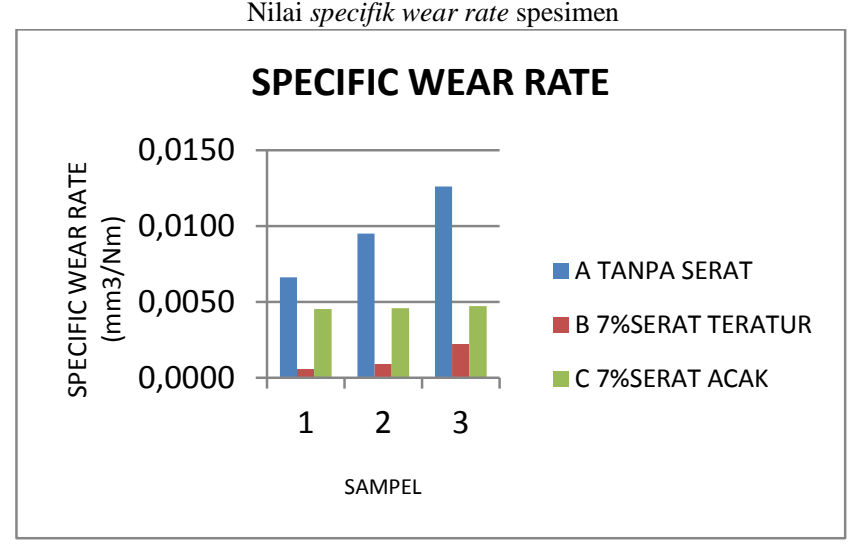

Gambar 1. Grafik nilai specifik wear rate spesimen

Dari gambar grafik, data nilai specific wear rate terlihat bahwa data nilai untuk pin B yaitu pin dari resin akrilik berpenguat $7 \%$ serat teratur adalah material uji yang memiliki nilai specific wear rate terkecil karena susunan serat yang sejajar menyebabkan pin ketika digesek dengan disk berpenguat serat acak maka serat pin yang saling bergesekan dengan material disk arah kikisannya memiliki kecenderungan yang konstan. Serat sebagai penguat resin memiliki sifat lebih keras dan kuat daripada resin akrilik sehingga nilai laju keausannya lebih rendah.

Nilai specific wear rate pada pin $\mathrm{C}$ berada di antara pin $\mathrm{A}$ dan $\mathrm{B}$. Hal ini dikarenakan pin $\mathrm{C}$ ini dari material resin akrilik berpenguat $7 \%$ serat acak. Ketika permukaan pin dengan serat acak digesek dengan permukaan disk berpenguat serat acak juga, letak susunan serat yang saling tidak beraturan satu sama lain ini memiliki kecenderungan saling mengikis dengan arah kikisan yang tidak konstan.Akibatnya, volume aus yang terjadi sedikit lebih banyak daripada resin akrilik berpenguat serat teratur. Nilai specific wear rate pin $\mathrm{C}$ pun sedikit lebih besar daripada pin $B$ yang berpola teratur.

Nilai specific wear rate terbesar terdapat pada pin A yaitu pin dari resin akrilik berpenguat $0 \%$ serat karena pada material pin A tidak ada serat sehingga ketika permukaannya digesek hanya material resin akrilik saja yang terkikis. Hal ini menyebabkan volume aus banyak terjadi dari resin akrilik. Pengaruh penambahan serat pada laju keausan menunjukkan bahwa laju keausan menurun karena adanya peran serat yang cukup optimal dalam menahan beban yang diterima komposit, sehingga laju 
keausan dapat ditekan. Bentuk dari sususan serat resin akrilik juga mempengaruhi nilai specific wear rate. Resin akrilik berpenguat $7 \%$ serat teratur terbukti dapat mengurangi nilai specific wear rate yang terjadi.

\section{E. Analisa Mekanisme Keausan}

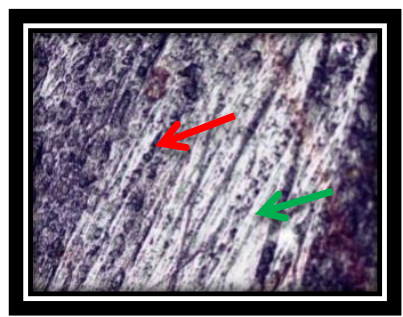

Gambar 11. Foto mikro pin resin akrilik berpenguat $0 \%$ serat

Pada gambar 11 dapat dilihat bahwa mekanisme keausan yang terjadi adalah abrasif dan fatigue. Panah berwarna hijau pada foto mikro menunjukkan adanya goresan-goresan yang mengindikasikan keausan abrasif. Goresan yang terjadi ini karena adanya partikel wear debris yang berfungsi sebagai bahan abrasif dimana wear debris meluncur pada permukaan material lain yang lebih lunak sehingga terjadi penetrasi atau pemotongan material yang lebih lunak.

Keausan fatigue juga ditunjukkan oleh panah berwarna merah yang terjadi karena material yang diuji keausan mengalami gesekan akibat adanya interaksi permukaan dimana permukaan yang mengalami beban berulang akan mengarah pada pembentukan retak-retak mikro yang kemudian menyatu dan menghasilkan pengelupasan pada permukaan material.
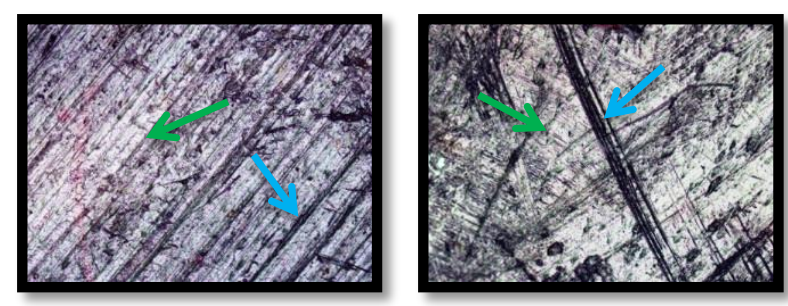

Gambar 12. Foto mikro pin resin akrilik berpenguat $7 \%$ serat berpola teratur (kiri) dan berpola acak (kanan)

Pada gambar 12 di atas, dapat dilihat bahwa mekanisme keausan yang dominan terjadi adalah keausan abrasif. Pada panah berwarna hijau tersebut menunjukkan adanya goresan-goresan akibat gesekan antar pemukaan spesimen dan juga adanya partikel wear debris sebagai bahan abrasif yang saling bergesekan dengan permukaan specimen. Pada panah biru menandakan bekas jejak letak dari serat. Jejak ini terbentuk karena adanya proses delaminasi. Delaminasi merupakan salah satu dari model kerusakan yang terjadi pada material komposit. Delaminasi bisa terjadi karena adanya konsentrasi tegangan pada lokasi retak di sekitar serat berada yang menyebabkan munculnya retak-retak mikro pada permukaan material yang kemudian menyatu dan menghasilkan pengelupasan serat dari matriksnya di permukaan material.

\section{KESIMPULAN}

Berdasarkan hasil studi eksperimental laju keausan spesifik material gigi tiruan dari resin akrilik berpenguat fiberglass dengan variasi susunan serat penguat $0 \%$ serat, $7 \%$ serat teratur, dan $7 \%$ serat acak menghasilkan kesimpulan, yaitu:
1) Nilai specific wear rate pada spesimen uji dari resin akrilik berpenguat $0 \%$ serat yaitu $0.0066 \mathrm{~mm}^{3} / \mathrm{Nm}$, $0.0095 \mathrm{~mm}^{3} / \mathrm{Nm}$, dan $0.0126 \mathrm{~mm}^{3} / \mathrm{Nm}$. Nilai specific wear rate pada spesimen uji dari resin akrilik berpenguat $7 \%$ serat berpola teratur yaitu 0,0006 $\mathrm{mm}^{3} / \mathrm{Nm}, 0.0009 \mathrm{~mm}^{3} / \mathrm{Nm}$, dan $0.0022 \mathrm{~mm}^{3} / \mathrm{Nm}$. Nilai specific wear rate pada spesimen uji dari resin akrilik berpenguat $7 \%$ serat berpola acak yaitu pin 0.0045 $\mathrm{mm}^{3} / \mathrm{Nm}, 0.0046 \mathrm{~mm}^{3} / \mathrm{Nm}$, dan $0.0047 \mathrm{~mm}^{3} / \mathrm{Nm}$.

2) Bentuk dari sususan serat resin akrilik juga mempengaruhi nilai specific wear rate. Nilai specific wear rate resin akrilik berpenguat $7 \%$ serat teratur terbukti dapat mengurangi nilai specific wear rate yang terjadi karena adanya peran serat yang cukup optimal dalam menahan beban yang diterima komposit.

3) Mekanisme keausan dari hasil foto mikro pada spesimen uji yang paling dominan adalah keausan abrasif karena adanya jejak dari partikel wear debris, serta keausan fatigue karena adanya jejak dari gesekan akibat pembebanan yang berosilasi terus-menerus sehingga menyebabkan pembentukan retak-retak mikro yang menghasilkan pengelupasan material.

\section{DAFTAR PUSTAKA}

[1] Widianingrum, Dwi Tarina, Studi Eksperimental Laju Keausan (Specific Wear Rate) Resin Akrilik dengan Penambahan Serat Penguat pada Dental Prosthesis, Jurnal Teknik ITS, Vol. 1, (Sept, 2012) ISSN: 2301-9271.

[2] Callaghan, David J., Ashkan Vaziri, Hamid Nayeb-Hashemi, Effect of Fiber Volume Fraction and Length on the Wear Characteristics of Glass Fiber-Reinforced Dental Composites, Journal at www.sciencedirect.com, Dental Material 22 (2006) 84-93, Elsevier, 2006.

[3] Sitorus, Zuriah, Eddy Dahar, Perbaikan Sifat Fisis dan Mekanik Resin Akrilik Polimerisasi Panas dengan Penambahan Serat Kaca, Dentika Dental Journal, Vol. 17. No. 1, 2012: 24-29.

[4] Gani, E. Pengaruh Perbedaan Waktu Perendaman Gigi dalam Minuman Berkarbonasi terhadap Kekutan Tekan (Compressive Strength) Gigi (In Vitro). 15 Mei 2016. http://repository.usu.ac.id/bitstream/123456789/42262/4/Ch apter\%20II.pdf.

[5] Zhou, Z.-R et al. 2013. Dental Biotribology. New York: Springer.

[6] Nurdiansyah, Yanto Ahmad dan Jamari, Dr., ST, MT. 2011. Perhitungan Keausan Berbasis FEM pada Sistem Rolling-Sliding Contact. Universitas Diponegoro. 